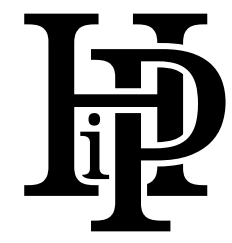

Historia i Polityka

No. 38(45)/2021, pp. 191-196

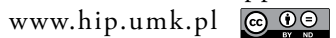

ISSN 1899-5160, e-ISSN 2391-7652

DOI: http://dx.doi.org/10.12775/HiP.2021.042

Marzena MRUK

University of Silesia, Faculty of Social Sciences, Katowice, Poland

\title{
Hanna Kupś, Maciej Szatkowski, Michał Dahl (Eds.). 70 lat Chińskiej Republiki Ludowej w ujęciu interdyscyplinarnym, Warszawa 2021, pp. 309
}

$\mathrm{T}$

he People's Republic of China, proclaimed on October 1, 1949, recently celebrated its $70^{\text {th }}$ anniversary in the international arena. Over the decades of operation, the Middle Kingdom has undergone numerous transformations in the sphere of internal and external politics, economic and technological development, or in activities aimed at maintaining the cultivation of Chinese tradition and culture. With the changing international system, the position of the People's Republic of China has grown significantly, making China one of the world powers whose aspirations are constantly growing. In order to better understand the situation of the contemporary People's Republic of China, a book entitled 70 lat Chińskiej Republiki Ludowej w ujęciu interdyscyplinarnym [70 Years of the People's Republic of China: An Interdisciplinary Perspective] was written, edited by Hanna Kupś, Maciej Szatkowski, and Michał Dahl. The publication was released on the market in 2021, thanks to cooperation with the Dialog Academic Publishing House. The book contains 309 pages of up-to- date information on the People's Republic of China, arranged in three sections: politics (4 articles), economy (6 articles), and culture ( 5 articles), which allows the reader to read Chinese politics in a clear and simple way according to the above division.

The first subsection, "Politics", opens with an article by Bogdan Góralczyk, entitled Chinski system polityczny - sui generis [Chinese Political System - Sui Generis], which is a very good introduction to the next part of this subsection, because without getting acquainted with the assumptions of the Chinese political system, it is difficult to continue further reflections on the policy of contemporary China. The author presents the readers with the changes taking place in the political system of the Middle Kingdom in an interesting and accessible way and smoothly moves from the Cold War period to the present situation in the PRC, thanks to which it can be seen how the Chinese political system has evolved over several decades and how this change influenced the position of the government in Beijing internationally. 
$O$ renesansie konfucjanizmu $w$ Chinach kontynentalnych $w$ okresie reform [On the Renaissance of Confucianism in Mainland China during the Reforms] by Marek Tylkowski refers to the important issue of the revival of Confucianism in the philosophical, political, scientific and social fields. Despite the fact that the history of Confucianism dates back to the $5^{\text {th }}$ century BCE, its foundations still remain an important element in the functioning of many Asian countries, including the People's Republic of China. In his work, the author emphasizes that the interest in Confucianism in contemporary China covers various social groups, from intellectual elites, through managers, to students, which may contribute to the fact that the PRC can cope well with the problems posed by Beijing in the modern world in the future. In addition, the subject taken up by the author and the facts presented by him clearly indicate that despite the vigorous Maoist propaganda and the changing political system of the People's Republic of China, old traditions are the foundation of the functioning of the state and their status will be difficult to change in the future.

Antonina Łuszczykiewicz is the author of the article entitled Chiny a Pięć Zasad Pokojowego Wspótistnienia $w$ dyskursie polityczno-kulturowym [China and the Five Principles of Peaceful Coexistence in the Political and Cultural Discourse]. The Five Principles of Peaceful Coexistence are key assumptions of Chinese foreign policy, which can already be found in the preamble to the 1982 Constitution of the People's Republic of China. The author of the article presents readers how the Chinese government applied these rules in particular years: 1954-1962, 1962-1988 and after 1988, and also refers in her work to numerous examples, often pointing to the changing level of effectiveness of the Principles in difficult Sino-Indian relations. The author rightly points out that the existence of the provision on the Principles of Peaceful Coexistence in the assumptions of Chinese foreign policy and their cultural background is an aspect completely independent of their actual application by the Beijing government.

The article concluding the section on Chinese politics is entitled $O$ wyższości polityki nad gospodarka i pierwszensstwie mechanizmów rynkowych przed politycznymi. Rola państwa w chińskiej polityce rozwoju regionalnego [On the Superiority of Politics over the Economy and the Priority of Market Mechanisms over Political Ones: The Role of the State in Chinese Regional Development Policy], and its author is Marek Świstak. In his work, the author tries to present the reader with a very complex problem that affects almost every country, especially in the process of rapid economic growth, i.e., differences in the economic development of regions, which in turn affects the situation of the entire country. The work clearly presents the characteristics of the Chinese planning system as an element of state activity in creating regional development, which allows for a clear understanding of the complexity of this phenomenon, characteristic of the People's Republic of China.

The second part of this publication is entitled "Economics" and begins with an article by Magdalena Rybicka, entitled Od imitacji do innowacji - rozwój rynku chinskiego $w$ XXI wieku [From Imitation to Innovation: The Development of the Chinese Market in the $21^{\text {st }}$ Century]. The author has taken up a very important issue in the $21^{\text {st }}$ century, i.e., the development of innovation as a key element of the economic development of the state. In addition to specifying the path of the People's Republic of China to openness to innovation and 
what changes have been undertaken by the authorities in Beijing over the years, the significance of China's accession to the World Trade Organization and the effects on the development of the Chinese economy were presented. An interesting issue taken up by Magdalena Rybicka is the presentation of the assumptions of the "Made in China 2025" strategy and an indication of the leading Chinese innovative industries in recent years, including: artificial intelligence, the Internet, self-propelled vehicles, and intelligent production.

Kamil Waligóra begins his article entitled Przeobrażenia gospodarcze ChRL - handel zagraniczny [Economic Transformations of the PRC: The Foreign Trade] with the key question, i.e., the theoretical introduction to the issue of foreign trade, which allows the reader to get acquainted with the topic from a purely theoretical point of view. In his work, the author outlines the three stages of the evolution of Beijing's trade policy, with particular emphasis on the People's Republic of China's most important export partners over several years. The article also emphasizes the very important and growing role of China in conducting electronic sales, as one of the most serious challenges for contemporary countries participating in foreign trade in the $21^{\text {st }}$ century.

Another article in this subsection entitled Regionalne zróżnicowanie dochodu dyspozycyjnego w Chinach [Regional Differentiation of Disposable Income in China], the author of which is Kamil Kotliński, is a comprehensive collection of information on the stratification of incomes in the People's Republic of China. It is worth mentioning at the outset that an important added value of the article is the results of the author's research, which are presented in an accessible way in the form of a table and graphs, from which the reader can easily get acquainted with the values that have changed over the years. As in the case of the previous article, Kamil Kotliński also presented a theoretical introduction to the issue under consideration, defining not only the issue of growth and stratification of regional development in the context of theory, but also pointed to numerous problems regarding the selection of measures enabling research and analysis of the above issue.

An interesting article, especially from the perspective of the current international situation, is Joanna Wardęga's article entitled Znaczenie turystyki dla międzynarodowej pozycji Chin [The Importance of Tourism to China's International Position]. The People's Republic of China has been enjoying growing attention of foreign tourists for several years, which is mainly due to the interest in Chinese culture, art and history. The author points to the elements that make China such an attractive travel destination, but also points to the fact that the Chinese have become the world's first group of nationalities in terms of the most frequent travelers, and that this trend will continue to grow in the coming years. The article also presents the use of tourism by the People's Republic of China as an element of Chinese soft power, especially in the context of relations with Japan, the Philippines, and South Korea. It should be noted, however, that this work covers the period until 2019; therefore, it does not contain information about the situation that has taken place since 2020 , i.e., the COVID-19 pandemic, and what impact the current pandemic situation in the world has on Chinese tourism. Nevertheless, it is a very interesting issue that is definitely worth following in the future.

Michał Zaremba in the article entitled Chińska pomoc rozwojowa. Stan i perspektywy [Chinese Development Aid: The Current State and Future Prospects] ana- 
lyzes the use of providing aid to other entities of international relations as an element serving not only to improve the situation of developing countries, but also to benefit China's own economy. The author, in an attractive way for the reader, divided his work into three parts, which provide an accessible way to familiarize oneself with the selected examples of international development aid system, the history of development aid provided by China and an analysis of the scale, nature and distribution of development aid provided by the PRC. Thanks to the charts showing, respectively, the net value of Chinese aid in 2001-2018 and the comparison of Chinese development aid expenditure with other countries, the reader can independently interpret and analyze the above phenomenon.

The article entitled Globalizacja handlu a synchronizacja cykli przeptywów gospodarczych między Chinami, USA i Unia Europejsk [Trade Globalization and the Synchronization of Economic Flow Cycles between China, the USA, and the European Union] by Adam Chlebisz and Mateusz Mierzejewski, completes the economics section of the publication. At the outset, the authors base their analysis on presenting the reader with the goals and methods used in the work, thanks to which the reader obtains not only practical and theoretical knowledge regarding this interesting issue. The article has been enriched with as many as 12 charts that clearly show the changing values in the three title subjects of international relations: China, the United States, and the European Union. The authors close their research by presenting very accurate conclusions that enable further analysis of the synchronization of economic flow cycles in subsequent years.

The last part of this publication is entitled "Culture" and it opens with an article by Natalia Lubińska and Monika Paliszewska-Mojsiuk, who undertook the analysis of education reforms in the People's Republic of China. Education of citizens is one of the basic tasks of the modern state. Over the centuries, the changing internal situation of China and its international environment has contributed to numerous changes and reforms in the educational system, which is a natural element of the country's development. In their work, the authors present these changes based on the following time frames: the period of the existence of the Chinese Empire and the functioning of the People's Republic of China from 1949 to 1978 and in the period after 1978, especially emphasizing the importance of the Cultural Revolution for education in China. It seems very important for Natalia Lubińska and Monika PaliszewskaMojsiuk to outline the Chinese educational system, which makes it possible to compare it with other systems in force in the modern world. The authors' conclusion is that the modern China should continue to invest in the education system, which will allow to meet the growing needs of the Chinese in the future.

Proces sinizacji grup etnicznych $w$ ChRL (i na Tajwanie) po 1949 roku w dyskursie etnolingwistycznym $i$ politycznym - przeglad glosariusza z komentarzem [The Process of Sinization of Ethnic Groups in the PRC (and Taiwan) after 1949 in Ethnolinguistic and Political Discourse: A Glossary Review with Commentary] is an article by Maciej Gaca, which refers to very important issues in the contemporary world, i.e., the notions of national unity, nationalism, and national consciousness. From the beginning of its existence, the People's Republic of China has been trying to determine not only the size of its population, but also its ethnic composition. Due to the fact that 
many ethnic and religious groups as well as the phenomenon of multilingualism exist in China, Beijing will face many challenges in the coming years in terms of creating and maintaining the national unity of all Chinese citizens. A very important topic taken up by the author in this article is the question of Taiwan, which is an area of key importance for the Chinese authorities, especially in the context of prestige. China, like many other multiethnic countries, is not free from the problem of reconciling cultural diversity with national integration, which is why the questions asked by the author in his conclusions seem right to ask: whether an intermediate model between these issues is possible at all and what conditions it should meet which gives the reader the opportunity to reflect on this issue further.

Another article entitled Rozwój kaligrafii w ChRL. Aspekt oświatowy [Development of Calligraphy in the PRC: An Educational Aspect] by Marek Piszczek includes a comprehensive analysis of the importance of calligraphy at the level of primary, secondary and higher education in the People's Republic of China over the years, from 1957 until now. The issue of Chinese calligraphy is something that fascinates millions of people in the world and is increasingly becoming the subject of scientific works. In his work, the author tries to present the development of calligraphy in the Chinese educational system in an accessible way, emphasizing that for several years it has been recognized as a separate specialty in the field of art sciences. In addition, the author also emphasizes the fact that the "calligraphy fever" that we have been dealing with in the PRC for several years is an element of return to tradition and culture that many Chinese in the globalized world are beginning to miss and appreciate.
Hanna Kupś in the article W poszukiwaniu źródet muzyki: rozwój archeologii muzycznej $w$ Chinach $w X X$ i XXI wieku [In Search of Music Genesis: The Development of Musical Archeology in China in the $20^{\text {th }}$ and $21^{\text {st }}$ Centuries] analyzes the development of an unusual phenomenon such as musical archeology. The article presents the evolution of musical archeology which dates back to the 1980s. Music, which is an element of the culture of each country, not only influences the shaping of contemporary societies, but also becomes an instrument of the rulers, which can be seen in the example of the People's Republic of China, where music is subject to ideological limitations. It should be noted, however, that the Chinese government has been supporting research on musical archeology for years, which allows Beijing to participate in international scientific cooperation, including promoting its culture and art, which definitely has a positive impact on the international perception of the People's Republic of China.

The article that ends this publication is an in-depth analysis conducted by Joanna Kucharzewska, who in the work entitled Trwanie i zmienność - architektura Pekinu $w$ ciagu ostatnich 70 lat [Duration and Variability: Beijing's Architecture over the Last 70 Years] presents the architectural assumptions for specific areas in the Chinese capital: government administration center, Tian'anmen Square, Qianmen Street, Chaoyang District and broadly understood housing architecture. The conclusions put forward by the author very accurately indicate that the architecture of Beijing since 1949 has been dependent on the political and economic situation in the state and on the reforms taking place in the state. It can be seen that the Chinese capital is an interesting combination of centuries-old tradi- 
tion and respect for culture with modernity and innovation. The added value of the article is undoubtedly the numerous photographs of the places discussed by the author (including the photos taken by Joanna Kucharzewska in 2009), thanks to which the reader, in addition to getting acquainted with the theoretical issues regarding Beijing's architecture, gets the opportunity to see the above-mentioned locations.

Despite the geographical and cultural distance, the People's Republic of China is in the center of attention of many Poles. The book edited by Hanna Kupś, Maciej Szatkowski and Michał Dahl is a very valuable compendium of knowledge in the field of research on the modern People's Republic of China, intended not only for special- ists in this field, but also for everyone interested in this issue - especially for students for whom the PRC is an area of scientific interests. In addition to the problems already known to many researchers, the publication deals with completely new issues, previously unheard of in the Polish literature on the subject, especially in the subsection on Chinese culture. The proposed topics presented in the studies are extremely interesting and diverse, very often supplemented with tables and charts that help to understand specific issues. Summing up, the studies included in the publication are characterized by high analytical and informative values. As the title suggests, the reader receives an interdisciplinary overview of changes taking place in the People's Republic of China since 1949. 